\title{
ЧИННИКИ, ЩО ВПЛИВАЮТЬ НА ПРОГНОЗ ПЕРЕБІГУ ГОСТРИХ ЛІМФОБЛАСТНИХ ЛЕЙКЕМІЙ У ДІТЕЙ
}

\author{
Бебешко В. Г. ${ }^{1}$, Бруслова К. М. ${ }^{1}$, Ляшенк о Л. О. ${ }^{1}$, Цвєткова Н. М. ${ }^{1}$, \\ Галкіна С. Г. ${ }^{1}$, Гончар Л. О. ${ }^{1}$, Боярська О. Я. ${ }^{2}$, Яцемирський С. М. ${ }^{1}$, \\ Пушкарьова Т. І. ${ }^{1}$, Трихліб І. В. ${ }^{1}$, Самсон Ю. М. ${ }^{1}$, Кавардакова Н. В. \\ ${ }^{1}$ ДУ «Національний науковий ичентр радіаџійної медицини НАМН України», \\ Київ, Україна \\ ${ }^{2}$ Д3 «Украйнський спеціалізований диспансер радіаційного захисту населення \\ МОЗ Украӥни», Київ, Украӥна
}

\begin{abstract}
Резюме
Мета. Визначити чинники, щуо впливають на прогноз перебігу гострих лімфобластних лейкемій (ГЛЛ) у дітей залежно від варіантів хвороби, стану стромального мікрооточення кісткового мозку, обміну заліза та гормональної регуляиії в динаміці лейкемічного процесу.

Матеріали і методи. Обстежено 100 осіб, які захворіли на ГЛЛ у дитячому вічі, у такі періоди: до лікування, період хіміотерапії, після хіміотерапї та у фазі ремісії. Тривалість ремісії становила від 5 до 25 років. Вивчали хвороби у родводі, показники гемограм $і$ мієлограм, прогноз перебігу ГЛЛ (виживання, летальні випадки). Досліджували рівні остеокальцину, паратгормону, кальцитоніну, кор.тизолу, вільного тироксину, тиреотропного гормону гіпофізу та феритину в сироватці крові, склад вільних амінокислот в сечі, активність лужної фосфатази, рівень кальцію в сироватціі крові, щүільність кісткової тканини.

Результати. Онкологічні хвороби у родоводі дітей з ГЛЛ реєструвались частіше, ніж в загальній популяиії (21,5\% проти 8,1\%). Кращий прогноз перебігу, за наявності у родоводі онкологічних хворих, був у групі дітей до 6 років; гірший - у осіб старше 12 років, родичі яких мали ендокринну патологію та алергічні реакиії. У $82 \%$ дітей ремісія тривала від 5 до 25 років (середня $(15,8 \pm 0,5)$ років). Максимальна виживаність була у дітей із «загальним» типом ГЛЛ, мінімальна з про-В-ГЛЛ та Т-ГЛЛ. Кількість летальних випадків у дітей старше 12 років була більша, ніж в групі хворих від 7 до 12 років. У дебюті ГЛЛ у $19 \%$ дітей були знижені рівні остеокальцину в сироватці крові та у $17 \%$ - кортизолу. Встановлено зворотний кореляційний зв'язок між вмістом кортизолу в дебюті ГЛЛ та вірогідністю розвитку рецидиву у хворих (rs =-0,67). Серед дітей з фізіологічним стромальним мікрооточенням було 6,6\% летальних випадків, зі змінами в показниках мікрооточення - 35,9\% (частка) ( $p<0,05)$. При проведенні хіміотерапії підвищувалась кількість паціснтів, особливо з рівнями феритину вище 500 нг/мл, щзо негативно впливало на прогноз перебігу ГЛЛ. Патологія
\end{abstract}


щчитоподібної залози виявлялась у хворих на ГЛЛ у перші 5-6 років після закінчення хіміотерапії $i$ становила 17,0\% (гіпотиреоз - 11,0\%, аутоімунний тиреоїдит - 5,0\%), у однієї дитини через 11 років після встановлення діагнозу ГЛЛ був діагностований папілярний рак щитоподібної залози (1,0\%). Гіпотиреоз виявлявся у осіб до 12 років, тиреоїдти - лише у хворих 7-12 років.

Висновки. Встановлені зміни в гормональній регуляції організму, котрі можуть бути промоторами злоякісного процесу, негативно впливати на метаболічні процеси та відігравати роль в прогнозі перебігу ГЛЛ у дітей.

Ключові слова: діти, гострі лімфобластні лейкемї, прогноз, стромальне мікрооточення, феритин, кортизол, остеокальцин, щчитоподібна залоза.

Конфлікт інтересів: автори заявляють про відсутність конфлікту інтересів.

Фінансування: дослідження не мало спонсорської підтримки.

\title{
FACTORS AFFECTING THE PROGNOSIS OF ACUTE LYMPHOBLASTIC LEUKEMIA IN CHILDREN
}

\author{
Bebeshko V. G. ${ }^{1}$, Bruslova K. M. ${ }^{1}$, Lyashenko L. O. ${ }^{1}$, Tsvyetkova N. M. ${ }^{1}$, \\ Galkina S. G. ${ }^{1}$, Gonchar L. O. ${ }^{1}$, Boyarska O. Ya. ${ }^{2}$, Iatsemyrskii S. M. ${ }^{1}$, \\ Pushkareva T. I. ${ }^{1}$, Trykhlib I. V. ${ }^{1}$, Samson Y. M. ${ }^{1}$, Kavardakova N. V. \\ ${ }^{I}$ SI «National Research Center for Radiation Medicine of the NAMS of Ukraine», \\ Kyiv, Ukraine \\ ${ }^{2}$ SI «Ukrainian Specialized Dispensary for Radiation Protection of the Population \\ of the MH of Ukraine», Kyiv, Ukraine
}

\begin{abstract}
Aim. Identify factors, that affect the prognosis of acute lymphoblastic leukemia (ALL) in children depending on the disease, the state of the stromal microenvironment of the bone marrow, iron metabolism, and hormonal regulation in the dynamics of the leukemic process.

Materials and methods. 100 patients with ALL were examined in all periods of the leukemic process (before treatment, chemotherapy, after chemotherapy, and in remission, which lasts from 5 to 25 years). We studied diseases in the pedigree, indicators of hemograms and myelograms, prognosis (survival, type of relapse, fatal outcome). Serum levels of osteocalcin, parathyroid hormone, calcitonin, cortisol, free thyroxine, pituitary thyroid hormone and ferritin, composition of free amino acids in urine, alkaline phosphatase activity, serum calcium levels, bone density were studied.

Results. Oncological diseases in the pedigree of children with ALL were registered more often than in the population $(21,5 \%$ vs. $8,1 \%)$. The best prognosis, in the presence of a pedigree of cancer patients, was in the group of children under 6 years; worse - in persons older than 12 years, whose relatives had endocrine pathology and
\end{abstract}


allergic reactions. In $82 \%$ of children, remission lasted from 6 to 25 years (mean (15.8 \pm 0.5$)$ years). Maximum survival was in children with "common» type of ALL, minimum - with pro-B-ALL and T-ALL. The number of deaths in children older than 12 years was higher than in the group of patients from 7 to 12 years. In the initial period of ALL, $19 \%$ of children had reduced levels of osteocalcin in the serum and $17 \%$ cortisol. An inverse correlation was found between the content of cortisol in the initial period of ALL and the probability of recurrence in patients ( $r s=-0,67)$. Among children with a physiological stromal microenvironment, $6.6 \%$ were fatal, with changes in the microenvironment $-35,9 \%$ (share) $(p<0,05)$. Chemotherapy increased the number of patients, especially with ferritin levels above $500 \mathrm{ng} / \mathrm{ml}$, which negatively affected the prognosis of ALL. Thyroid pathology was detected in patients with GLL in the first 56 years after chemotherapy and amounted to 17,0\% (hypothyroidism 11,0\%, autoimmune thyroiditis - 5,0\%). One child was diagnosed with papillary thyroid cancer 11 years after being diagnosed with ALL. Hypothyroidism was found in persons under 12 years of age, thyroiditis - only in patients 7-12 years.

Conclusions. Changes in the hormonal regulation of the body, which can be promoters of the malignant process, adversely affect metabolic processes and play a role in predicting the course of ALL in children.

Keywords: children, acute lymphoblastic leukemia, prognosis, stromal microenvironment, ferritin, cortisol, osteocalcin, thyroid gland.

\section{Вступ}

В етіології гострих лімфобластних лейкемій (ГЛЛ) певну роль відіграють фактори навколишнього середовища, генетична компонента, іонізуюче випромінювання, попередня хіміотерапія (XT) або променева терапія, а також такі гени як ARD5B та IKZF1, що беруть участь у лімфоїдній диференціації і підвищують ризик розвитку цієї патології у дітей [1]. На прогноз перебігу ГЛЛ впливають ускладнення, які виникають у хворих на ГЛЛ під час індукційної та реіндукційної хіміотерапії. У $25,0 \%$ це була пневмонія, в 16,4\% - гіперглікемія, в 15,6 \% - гепатит, 13,3 \% - гіпертонія. У фазі індукції частота ускладнень складала 32,6 \%, у фазі консолідації - 19,4 \% [2].

Відновлення кісткового мозку після цитостатичної мієлосупресії у хворих залежало від варіантів В-ГЛЛ (про-В, «загальний тип», пре-В) та Т-ГЛЛ. Відмічено, що за наявності прогностично несприятливого варіанту захворювання про-В-ГЛЛ у мієлограмі хворих була підвищена кількість еритроїдних елементів $(47,2 \pm 3,6) \%$, тоді як у інших в цей період превалювали гранулоцитарні елементи і моноцити [3]. На виживаність дітей впливають такі фактори як стан стромального мікрооточення, надлишок заліза в організмі, ініціальний рівень ендогенного кортизолу [4], частота та тривалість перерв при проведенні протоколу ХТ [5]. 
За останні 50 років виживання дітей з ГЛЛ суттєво зросло. Оптимальне використання антилейкемічних засобів за протоколами кооперативних груп, профілактика ураження центральної нервової системи, удосконалення терапії супроводу покращили 5-річний показник виживання без рецидивів до $85 \%$. Ускладнення у пацієнтів були пов'язані з підвищеним ризиком таких несприятливих наслідків, як рання смерть, вторинні злоякісні захворювання, неврологічні, серцеві, ендокринні та психологічні розлади [6]. Виявлена роль моноцитів в прогнозі перебігу захворювання [7].

Деякі автори оцінювали частоту та фактори ризику дисфункції щитоподібної залози у дітей, які пережили гостру лейкемію. Показано, що через 10-20 років після діагностики лейкемії частота гіпотиреозу у хворих становила 17,3\%, раку щитоподібної залози - 5,2 \%. Причому, пацієнти старші 10 років мали нижчий ризик розвитку патології щитоподібної залози [8]. Тому важливо визначити чинники, що впливають на прогноз перебігу ГЛЛ у пацієнтів, які захворіли у дитячому віці, особливо у віддалений період.

Мета - визначити чинники, що впливають на прогноз перебігу ГЛЛ у дітей залежно від варіантів хвороби, стану стромального мікрооточення кісткового мозку, обміну заліза та гормональної регуляції в динаміці лейкемічного процесу.

\section{Матеріали і методи}

Обстежено 100 осіб, які захворіли на ГЛЛ у дитячому віці. Хлопчиків було 58, дівчат - 42. Діагноз ГЛЛ встановлено на підставі морфологічної оцінки бластних клітин кісткового мозку за ФАБ-класифікацією, субпопуляційного складу імунокомпетентних клітин, експресії поверхневого фенотипу. Вік дітей враховували на час встановлення діагнозу. Згідно 3 протоколом розподіл дітей за віком був до 6 років та старше 6 років. Водночас, нами була сформована третя вікова група, до якої увійшли діти від 7 до 12 років, з урахуванням вікової періодизації та періоду інтенсивності росту. Хворим проводили ХТ за адаптованими протоколами БерлінФранкфурт-Мюнстер групи (BFM). Були проаналізовані результати досліджень: до лікування, при проведенні XТ, після закінчення протоколу ХT та в період повної гематологічної ремісії (5-25 років). Оцінювали наявність хвороб у родоводі дітей (онкологічні, ендокринні та алергічні реакції: медикаментозні, харчові, полівалентні), показники гемограм i мієлограм, прогноз перебігу ГЛЛ (виживання, летальні випадки).

Розподіл хворих за віковими групами та імунофенотиповими варіантами ГЛЛ надано в таблиці 1. Дітей із «загальним» типом ГЛЛ було 73 \%. 
Найменше хворих було на про-В-ГЛЛ та Т-ГЛЛ, відповідно 6,0\% та $8,0 \%$. Половина хворих була до 6 років. Старше 12 років було $18 \%$. Незалежно від віку дітей, превалював «загальний» тип ГЛЛ.

\section{Таблиця 1. Розподіл хворих за віковими групами та варіантами ГЛЛ}

\begin{tabular}{|l|c|c|c|c|c|}
\hline \multirow{2}{*}{$\begin{array}{c}\text { Вікові групи } \\
\text { (роки) }\end{array}$} & \multicolumn{5}{|c|}{ Варіанти ГЛЛ } \\
\cline { 2 - 6 } & Всього & Про-В & $\begin{array}{c}\text { «загальний» } \\
\text { тип }\end{array}$ & Пре-В & Т-ГЛЛ \\
\hline $1-6$ & 54 & 2 & 44 & 6 & 2 \\
\hline $7-12$ & 28 & 4 & 18 & 5 & 1 \\
\hline Старше 12 & 18 & 2 & 11 & 2 & 3 \\
\hline Разом & 100 & $8(8,0 \%)$ & $73(73,0 \%)$ & $13(13,0 \%)$ & $6(6,0 \%)$ \\
\hline
\end{tabular}

Показники гемограми досліджували на автоматичному гемоаналізаторі MicroCC-18 (США). Елементи мієлограми підраховували в світловому мікроскопі (збільшення $\times 1000)$ після забарвлення препаратів кісткового мозку за Романовським-Гімзою. Рівні гормонів (остеокальцину (ОстеоКа), парат-гормону (ПТГ), кальцитоніну (КТ), кортизолу, вільного тироксину $\left(\mathrm{FT}_{4}\right)$, тиреотропного гормону гіпофізу (ТТГ) та феритину в сироватці крові вивчали за допомогою радіоімунного методу (RIA-Kits). Склад вільних амінокислот в сечі визначали на аналізаторі амінокислот типу Т-339 (Чехія). Активність лужної фосфатази (ЛФ), рівень кальцію в сироватці крові вивчали на біохімічному аналізаторі Humostar-600 (Німеччина). Щільність кісткової тканини досліджували на денситометрі Ultrasonometer Lunar (США) за Т-показником.

Дослідження виконані з дотриманням положень Гельсінської декларації Всесвітньої медичної асоціації «Етичні принципи медичних досліджень за участю людини у якості об'єкта дослідження». Батьки або родичі хворих підписували інформовану згоду на участь у дослідженні, вжиті всі заходи для забезпечення анонімності пацієнтів.

Обробку отриманих матеріалів проводили за методами математичної статистики (коефіцієнт кореляції Стьюдента, Спірмена; метод інтервального оцінювання - MIO) (https://www.psychol-ok.ru/lib/statistics.html).

\section{Результати та їх обговорення}

Нами виявлено вплив патології у родоводі хворих на прогноз перебігу ГЛЛ у дітей. Показано, що онкологічні хвороби частіше реєструвались у родичів дітей з ГЛЛ, ніж в групі порівняння (21,5\% проти $8,1 \%)$ $(\mathrm{p}<0,05)$. За наявності алергічних реакцій у родоводі частіше 
захворювали хлопчики, ніж дівчата (rs $=0,46)$. За наявності у родоводі онкологічних хвороб, кращий прогноз перебігу був у дітей з ГЛЛ до 6 років ((136,4 $\pm 4,7)$ міс.). За наявності у родоводі ендокринної патології та алергічних реакції гірший прогноз був у осіб старше 12 років ((56,5 $\pm 4,3)$ міс.). В анамнезі дітей з ГЛЛ частіше реєструвались травми кісток $(\mathrm{p}<0,05)$.

В дебюті ГЛЛ у хворих на «загальний» тип та пре-В-ГЛЛ рівень гемоглобіну був достовірно нижче, порівняно з середнім показником при ГЛЛ, і складав відповідно $(77,8 \pm 2,0)$ г/л, $(68,3 \pm 6,1)$ г/л та $(86,1 \pm 4,3)$ г/л. При Т-ГЛЛ та про-В-ГЛЛ вміст гемоглобіну у хворих був вище: $(99,5 \pm 3,2)$ г/л та $(98,7 \pm 4,1)$ г/л, відповідно. Анемії у хворих мали нормоцитарно-нормохромний характер. Ініціальне число лейкоцитів було нижче при «загальному» типі $((17,9 \pm 3,0)$ Г/л) та пре-В-ГЛЛ $((9,6 \pm 2,3)$ Г/л), вище - при Т-ГЛЛ ((42,1 $\pm 5,3)$ Г/л) та про-В-ГЛЛ $(61,3 \pm 8,2)$ Г/л). Число тромбоцитів у хворих не досягало стандартних величин і було вище тільки за наявності Т-ГЛЛ ( $<<0,05)$. В гострий період хвороби результати мієлограм хворих свідчили про порушення процесів проліферації та диференціювання елементів гемопоезу.

На теперішній час в клініко-гематологічній ремісії $((16,8 \pm 0,8)$ років) знаходиться 82 \% дітей (табл. 2). Максимальна виживаність спостерігалась у дітей із «загальним» типом хвороби, мінімальна - 3 про-В-ГЛЛ та Т-ГЛЛ (p < 0,05). Летальні випадки становили $18 \%$. Серед дітей старше 12 років число летальних випадків було більше, ніж в групі хворих від 7 до 12 років ( $<0,05)$. Між кількістю померлих пацієнтів до 6 років та від 7 до 12 років різниці не встановлено.

\section{Таблиця 2. Розподіл хворих на ГЛЛ за віковими групами та результатом лікування (жива дитина/летальний випадок)}

\begin{tabular}{|l|c|c|c|c|}
\hline \multirow{2}{*}{$\begin{array}{c}\text { Вікові } \\
\text { групи } \\
\text { (роки) }\end{array}$} & \multicolumn{4}{|c|}{ Результат лікування } \\
\cline { 2 - 5 } & Всього & $\begin{array}{c}\text { Хлопчики/ } \\
\text { дівчата }\end{array}$ & $\begin{array}{c}\text { Жива } \\
\text { дитина }\end{array}$ & $\begin{array}{c}\text { Летальний } \\
\text { випадок }\end{array}$ \\
\hline $1-6$ & 54 & $31 / 23$ & 44 & 10 \\
\hline $7-12$ & 28 & $15 / 13$ & 25 & $3^{*}$ \\
\hline Старше 12 & 18 & $12 / 6$ & 13 & 5 \\
\hline Разом & 100 & $58 / 42$ & 82 & 18 \\
\hline
\end{tabular}

Примітка: * - різниця між числом летальних випадків у дітей від 7-12 років та старше 12 років $(\mathrm{p}<0,05)$ 
Враховуючи інтегральні механізми регуляції процесів метаболізму, зокрема, стромального мікрооточення, кістковомозкового кровотворення, обміну заліза та регуляторної дії ендокринної системи, нами були проаналізовані зв'язки між відповідними показниками. Так, рівень остеокальцину, що відображає процеси остеоутворення і ремоделювання кісток, у $19 \%$ дітей з ГЛЛ, був знижений як в гострий період $((27,08 \pm 5,41)$ нг/мл), так і в ремісії $((32,5 \pm 4,2)$ нг/мл), порівняно 3 пацієнтами без онкогематологічної патології $((58,3 \pm 3,9)$ нг/мл) (p $<0,05)$.

Нами встановлено, що функція стромальних фібробластів кісткового мозку, котрі беруть участь у синтезі колагену та формують гемопоетичне мікрооточення, залежить від рівня кортизолу: чим нижчі рівні кортизолу, тим менша активність фібробластів і тим більші зміни реєструються в процесах колагеноутворення. При цьому підвищується рівень лужної фосфатази в сироватці крові, збільшується екскреція оксипроліну та пірофосфатів кальцію 3 сечею, спостерігається дисбаланс рівня амінокислот, що входять до складу колагену (гліцин, лізин, аргінін, пролін). Водночас, за низької щільності кісткової тканини пацієнти були резистентні до ХТ і виживаність у них була коротшою [9]. Встановлено зворотний кореляційний зв'язок між вмістом кортизолу в початковий період ГЛЛ та вірогідністю розвитку рецидиву у хворих $(\mathrm{rs}=-0,67)$ [4]. Прояви гіпокортизолемії у хворих в дебюті ГЛЛ супроводжувались уповільненням процесів репарації кісткових структур, змінами в стромальному мікрооточенні, проявами остеопенії та остеопорозу. При збільшенні рівнів ТТГ вище за $(3,3 \pm 0,12)$ Од/л вірогідно підвищувалась екскреція оксипроліну з сечею $(\mathrm{p}<0,05)$. Тобто, фізіологічний стан стромального мікрооточення знаходиться під впливом низки гормонів, в тому числі щитоподібної залози, і залежить від процесів колагеноутворення, рівнів амінокислот, складових метаболізму кісткової тканини та ії щільності.

Ми провели порівняльну оцінку кількості летальних випадків у дітей 3 ГЛЛ залежно від стану стромального мікрооточення (табл. 3).

Не виявлено різниці між кількістю летальних випадків у хворих групи стандартного та середнього прогностичного ризику (частка $11,6 \%$ та 10,8 \% відповідно). Водночас, у дітей групи високого ризику число летальних випадків превалювало (8 з 12). Звертає на себе увагу вірогідна різниця між кількістю летальних випадків у хворих стандартної та середньої груп ризику залежно від стану стромального мікрооточення. Так, серед 61 дитини, незалежно від групи терапевтичного ризику, 3 фізіологічними показниками мікрооточення за станом остеону було 4 летальні випадки $(6,6 \%)$. Водночас, серед 39 дітей зі змінами в показниках мікрооточення спостерігалось 14 летальних випадків (частка 35,9 \%) (p < 0,05)). 


\section{Таблиця 3. Розподіл дітей, хворих на ГЛЛ, за групами ризику, станом стромального мікрооточення та летальними випадками}

\begin{tabular}{|l|c|c|c|c|}
\hline \multirow{2}{*}{$\begin{array}{c}\text { Група ризику за } \\
\text { протоколом ВFM }\end{array}$} & \multicolumn{4}{|c|}{ Стан стромального мікрооточення } \\
\cline { 2 - 5 } & Фізіологічні показники & \multicolumn{2}{|c|}{ Зміни в показниках } \\
\cline { 2 - 5 } & Всього & $\begin{array}{c}\text { Летальні } \\
\text { випадки }\end{array}$ & Всього & $\begin{array}{c}\text { Летальні } \\
\text { випадки }\end{array}$ \\
\hline Стандартна, $\mathrm{n}=51$ & 33 & 1 & 18 & 5 \\
\hline Середня, $\mathrm{n}=37$ & 26 & 1 & 11 & 3 \\
\hline Висока, $\mathrm{n}=12$ & 2 & 2 & 10 & 6 \\
\hline Разом, $\mathrm{n}=100$ & 61 & $4^{*}$ & 39 & 14 \\
\hline
\end{tabular}

Примітка: * - різниця між кількістю летальних випадків та станом стромального мікрооточення $(\mathrm{p}<0,05)$

Ми визнали за доцільне проаналізувати чинники, що можуть впливати на прогноз перебігу ГЛЛ і порівняли показники залежно від виживання хворих. До першої групи увійшли діти, які одужали після захворювання на ГЛЛ, до другої - хворі з летальним результатом. Враховували регуляторні чинники, показники метаболізму остеогенезу, обміну заліза в динаміці лейкемічного процесу (табл. 4). До початку протоколу ХТ кількість хворих зі зниженими рівнями регуляторних чинників процесів остеоутворення (остеокальцин, кортизол в сироватці крові) була більша серед дітей 2 групи (Остеокальцин. МIO. I-a границя: 0,89-0,85-0,79; 2-а границя: 0,74-0,61-0,45; p <0,05); (Кортизол. МІО. 1-а границя: 0,91-0,87-0,82; 2-а границя: 0,74-0,61-0,45; p <0,05). Не визначено різниці в рівнях кальцитоніну та паратиреоїдного гормону в сироватці крові у дітей. Водночас, більша кількість хворих зі змінами в мікрооточенні в цей період була серед пацієнтів 3 несприятливим перебігом хвороби (MIO. 1-а границя: 0,89-0,85-0,80; 2-а границя: 0,59-0,41-0,30) $(\mathrm{p}<0,05)$. На всіх етапах ХT діти з летальним результатом мали зміни в стромальному мікрооточенні. Кількість дітей з підвищеним рівнем феритину в сироватці крові в дебюті ГЛЛ була більше серед осіб 2 групи. В динаміці проведення ХТ кількість хворих зростала, особливо з рівнями феритину вище 500 нг/мл (МIO. I-а границя: 0,910,87-0,82; 2-а границя: 0,64-0,50-0,35) ( $<<0,05)$.

Причинами перевантаження організму залізом у хворих були, як правило, переливання концентратів еритроцитів. Відомо, що надлишок заліза в організмі активізує вільнорадикальні процеси та сприяє проявам фероптозу [10]. Слід зазначити, що майже у всіх дітей з летальними випадками, підвищений рівень феритину в сироватці крові сполучався зі зниженим ініціальним рівнем кортизолу та змінами в стромальному мікрооточенні. 
Таблиця 4. Розподіл дітей з ГЛЛ за періодами, рівнями показників у рангах: $\downarrow$ - нижче нормативного, $\uparrow$ - вище нормативного, і результатом хвороби (\# - рівень феритину в сироватці крові вищий 500 нг/мл)

\begin{tabular}{|c|c|c|c|c|c|c|}
\hline \multirow{2}{*}{ Показник } & \multicolumn{3}{|c|}{$\begin{array}{c}\text { Число дітей без } \\
\text { рецидивів }(\mathbf{n}=82)\end{array}$} & \multicolumn{3}{|c|}{$\begin{array}{c}\text { Летальні випадки } \\
(\mathrm{n}=18) \\
\end{array}$} \\
\hline & $\begin{array}{l}\text { I період } \\
\text { до XT }\end{array}$ & XT & $\begin{array}{l}\text { Після } \\
\text { ХT }\end{array}$ & $\begin{array}{l}\text { I період } \\
\text { до XT }\end{array}$ & XT & $\begin{array}{l}\text { Після } \\
\text { ХT }\end{array}$ \\
\hline$\downarrow$ ОстеоКа & $12^{*}$ & - & 5 & $7^{*}$ & - & - \\
\hline$\downarrow$ Кортизол & $10^{*}$ & - & 4 & $7^{*}$ & - & 6 \\
\hline$\uparrow \mathrm{TT} \Gamma$ & $3^{*}$ & $6^{*}$ & $6^{*}$ & 2 & 4 & 4 \\
\hline Зміни в мікрооточенні & $14^{*}$ & $21^{*}$ & $11^{*}$ & 10 & 18 & 18 \\
\hline$\uparrow$ Феритин & $10^{*}$ & $26 / 11^{\#}$ & $21 / 7^{\#}$ & 8 & $9 / 9^{\#}$ & $12 / 7^{\#}$ \\
\hline Змін не було & 43 & 30 & 33 & - & - & - \\
\hline
\end{tabular}

Примітка: ${ }^{*}$ - різниия між показником в межах одного періоду $(p<0,05)$

Ми окремо зупинились на групі дітей 3 патологією щитоподібної залози, яка виявлялась в перші п'ять-шість років після закінчення курсу ХT. Причому, у цих дітей при проведенні ХT не було ні клінічних, ні лабораторних проявів патології щитоподібної залози.

\section{Таблиця 5. Розподіл хворих на ГЛЛ за віковими групами} та патологісю щитоподібної залози у віддалений період

\begin{tabular}{|l|c|c|c|c|}
\hline \multirow{2}{*}{$\begin{array}{c}\text { Вікові групи } \\
\text { (роки) }\end{array}$} & \multicolumn{4}{|c|}{ Патологія щитоподібної залози } \\
\cline { 2 - 5 } & Гіпотиреоз & Тиреоїдит & Рак & Всього \\
\hline $1-6$ & 7 & - & - & 7 \\
\hline $7-12$ & 4 & 5 & 1 & 10 \\
\hline Старші 12 & - & - & - & - \\
\hline Разом & 11 & 5 & 1 & 17 \\
\hline
\end{tabular}

Сукупна частота патології щитоподібної залози, яка виявлялась у дітей, становила 17,0 \%. Гіпотиреоз діагностувався у 11,0\%, аутоімунний тиреоїдит - у 5,0\%. У однієї дитини (1,0\%) через 11 років після встановлення діагнозу ГЛЛ був діагностований папілярний рак щитоподібної залози. Всі хворі з патологією щитоподібної залози мали «загальний» тип ГЛЛ. Серед дітей з гіпотиреозом не було осіб старше 12 років. Водночас, тиреоїдити було діагностовано у хворих 7-12 років. Тобто, зміни у функціонуванні щитоподібної залози у дітей можуть бути предиктором злоякісного процесу. 
У таблиці 6 узагальнені маркери прогнозу перебігу ГЛЛ у дітей.

Таблиця 6. Маркери прогнозу перебігу ГЛЛ у дітей

\begin{tabular}{|l|c|c|c|}
\hline \multicolumn{1}{|c|}{ Показники } & $\begin{array}{c}\text { Сприятливий } \\
\text { прогноз ГЛЛ } \\
\text { (>60 міс.) }\end{array}$ & $\begin{array}{c}\text { Несприятливий } \\
\text { прогноз ГЛЛ } \\
\text { (<60 міс.) }\end{array}$ & Ранги* \\
\hline \multicolumn{3}{|c|}{ Регуляторні фактори } \\
\hline $\begin{array}{l}\text { Остеокальцин в сироватці крові, } \\
\text { нг/мл }\end{array}$ & $>25$ & $<60$ & 1 \\
\hline Кортизол в сироватці крові, нмоль/л & $>160$ & $<160$ & 1 \\
\hline \multicolumn{3}{|c|}{ Маркери метаболізму } \\
\hline О-пролін в сечі, мкмоль/л & $<11,0$ & $>11,0$ & 2 \\
\hline Пролін в сечі, кмоль/л & $<0,8$ & $>1,0$ & 2 \\
\hline Гліцин в сечі, кмоль/л & $>17$ & $<17$ & 2 \\
\hline ЛФ в сироватці крові, Од/л & Норма & $<200 ;>600$ & 2 \\
\hline Са в сироватці крові, ммоль/л & $>2,3$ & $<2,1$ & 2 \\
\hline Щільність кісток, ум.од. & $>65$ & $<65$ & 3 \\
\hline Феритин в сироватці крові, мгмл & $<200$ & $>500$ & 4 \\
\hline
\end{tabular}

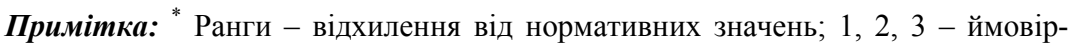
ність впливу показника на прогноз, відповідно формулі Байєса

Таким чином, аналіз отриманих даних показав, що у хворих на ГЛЛ у динаміці лейкемічного процесу відмічаються зміни гормональної регуляції, які реалізуються через різні регуляторні системи і негативно впливають на фізіологічні процеси та здійснюють парціальний внесок в патологію на організменному рівні.

\section{Висновки}

1. Онкологічні хвороби у родоводі дітей з ГЛЛ реєструвались в $21,5 \%$ проти $8,1 \%$ в групі порівняння $(\mathrm{p}<0,05)$. За наявності у родоводі онкологічних хвороб, кращий прогноз перебігу був у дітей з ГЛЛ до 6 років $((136,4 \pm 4,7)$ міс.), ендокринної патології та алергічних реакції - гірший прогноз у осіб старше 12 років ((56,5 $\pm 4,3)$ міс.). За наявності алергічних реакцій у родоводі частіше захворювали хлопчики, ніж дівчата $(\mathrm{rs}=0,46)$.

2. У $82 \%$ обстежених осіб ремісія тривала від 5 до 25 років (середня $(15,8 \pm 0,5)$ років). Максимальна виживаність була у дітей із «загальним» типом ГЛЛ, мінімальна - 3 про-В-ГЛЛ та Т-ГЛЛ (р < 0,05). Кількість летальних випадків у дітей старше 12 років була більша, ніж в групі хворих від 7 до 12 років $(\mathrm{p}<0,05)$. 
3. У дебюті ГЛЛ у $19 \%$ дітей були знижені рівні остеокальцину в сироватці крові та у $17 \%$ - кортизолу. Встановлено зворотний кореляційний зв'язок між вмістом кортизолу до початку призначення терапії ГЛЛ та вірогідністю розвитку рецидиву у хворих $(\mathrm{rs}=-0,67)$. Серед дітей з фізіологічним станом стромального мікрооточення було 6,6\% летальних випадків, зі змінами в показниках мікрооточення - 35,9\% (частка) $(\mathrm{p}<0,05)$.

4. У дебюті ГЛЛ кількість дітей 3 підвищеним рівнем феритину в сироватці крові була більша серед осіб, які в подальшому померли. При проведенні ХТ підвищувалось число пацієнтів, особливо 3 рівнями феритину вище 500 нг/мл, що свідчить про надлишок заліза в організмі, який негативно впливає на прогноз перебігу захворювання.

5. Патологія щитоподібної залози виявлялась у 17,0 \% хворих на ГЛЛ в перші 5-6 років після закінчення ХТ і становила: гіпотиреоз 11,0\%, аутоімунний тиреоїдит - у 5,0\%. У однієї дитини (1,0\%) через 11 років після встановлення діагнозу ГЛЛ був діагностований папілярний рак щитоподібної залози. Гіпотиреоз виявлявся у осіб до 12 років, тиреоїдити - лише у хворих 7-12 років.

\section{Література}

1. Puckett Y, Chan O. Acute lymphocytic leukemia. StatPearls [Internet]. Treasure Island (FL): StatPearls Publishing. 2021 Jan [cited 2021 Apr 13].

2. Ayhan A, Timur C, Kalaycik O. A retrospective analysis of complications observed in children with acute lymphoblastic leukemia during chemotherapy. Minerva Pediatr. 2017 Apr; 69(2):95-105. DOI: 10.23736/ S0026-4946.16.04239-0.

3. Bebeshko VG, Bruslova KM, Pushkareva TI, Tsvyetkova NM, Lyashenko LO, Kuznyetsova Oye, et al. State of erythroid, granulocyte and platelet branches of hematopoiesis on stages of chemotherapy in children with acute lymphoblastic leukemia, who were exposed to ionizing radiation after the Chornobyl NPP accident.

\section{Reference}

1. Puckett Y, Chan O. Acute lymphocytic leukemia. StatPearls [Internet]. Treasure Island (FL): StatPearls Publishing. 2021 Jan [cited 2021 Apr 13].

2. Ayhan A, Timur C, Kalaycik O. A retrospective analysis of complications observed in children with acute lymphoblastic leukemia during chemotherapy. Minerva Pediatr. 2017 Apr; 69(2):95-105. DOI: 10.23736/ S0026-4946.16.04239-0.

3. Bebeshko VG, Bruslova KM, Pushkareva TI, Tsvyetkova NM, Lyashenko LO, Kuznyetsova Oye, et al. State of erythroid, granulocyte and platelet branches of hematopoiesis on stages of chemotherapy in children with acute lymphoblastic leukemia, who were exposed to ionizing radiation after the Chornobyl NPP accident. 
Probl. Radiac. Med. Radiobiol. 2016; 21:178-90.

4. Bebeshko VG, Bruslova KM, Pushkareva TI, Tsvyetkova NM, Lyashenko LO, Kuznyetsova Oye, Sergeeva AS, et al. Cortisol level as risk factor for malignant hematologic pathology in children exposed to ionizing radiation after Chornobyl accident. Probl. Radiac. Med. Radiobiol. 2017; 22: 306-15.

5. Bebeshko VG, Bruslova KM, Tsvyetkova NM, Lyashenko LO, Pushkareva TI, Gonchar LO, et al.Prognosis of the course of Chornobyl-originated acute lymphoblastic leukemia in children in Ukraine depending on the reason of standard chemotherapy interuption. Probl. Radiac. Med. Radiobiol. 2019; 24: 335-49.

6. Kizilocak H, Okcu F. Late effects of therapy in childhood acute lymphoblastic leukemia survivors. Turk J Haematol. 2019 Feb 7; 36(1): $1-11$.

DOI: 10.4274/tjh.galenos.2018.2018.0150

7. Witkowski MT, Dolgalev I, Evensen NA, Ma Ch, Chambers T, Roberts $\mathrm{KG}$, et al. Extensive remodeling of the immune microenvironment in B cell acute lymphoblastic leukemia. Cancer Cell. 2020 Jun 8; 37(6): 86782. DOI: 10.1016/j.ccell.2020.04.015

8. Oudin C, Auquier P, Bertrand Y, Chastagner P, Kanold J, Poirée M, et al. Late thyroid complications in survivors of childhood acute leukemia. An L.E.A. study. Haematologica. 2016 Jun; 101(6); 747-56. DOI: 10.3324/haematol.2015.140053

9. Бебешко ВГ, Пристер БС, Омельянець МІ, редактори. Радіобіофі-
Probl. Radiac. Med. Radiobiol. 2016; 21:178-90.

4. Bebeshko VG, Bruslova KM, Pushkareva TI, Tsvyetkova NM, Lyashenko LO, Kuznyetsova Oye, Sergeeva AS, et al. Cortisol level as risk factor for malignant hematologic pathology in children exposed to ionizing radiation after Chornobyl accident. Probl. Radiac. Med. Radiobiol. 2017; 22: 306-15.

5. Bebeshko VG, Bruslova KM, Tsvyetkova NM, Lyashenko LO, Pushkareva TI, Gonchar LO, et al. Prognosis of the course of Chornobyloriginated acute lymphoblastic leukemia in children in Ukraine depending on the reason of standard chemotherapy interruption. Probl. Radiac. Med. Radiobiol. 2019; 24: 335-49.

6. Kizılocak H, Okcu F. Late effects of therapy in childhood acute lymphoblastic leukemia survivors. Turk J Haematol. 2019 Feb 7; 36(1): $1-11$.

DOI: 10.4274/tjh.galenos.2018.2018.0150

7. Witkowski MT, Dolgalev I, Evensen NA, Ma Ch, Chambers T, Roberts $\mathrm{KG}$, et al. Extensive remodeling of the immune microenvironment in B cell acute lymphoblastic leukemia. Cancer Cell. 2020 Jun 8; 37(6): 86782. DOI: 10.1016/j.ccell.2020.04.015

8. Oudin C, Auquier P, Bertrand Y, Chastagner P, Kanold J, Poirée M, et al. Late thyroid complications in survivors of childhood acute leukemia. An L.E.A. study. Haematologica. 2016 Jun; 101(6); 747-56. DOI: $10.3324 /$ haematol.2015.140053

9. Bebeshko VG, Prister BS, Omelyanets MI, editors. Radiobiophysical 
зичні та медико-гігієнічні наслідки Чорнобильської катастрофи: шляхи пізнання та подолання: Практичний посібник сімейного лікаря. Ужгород: Патент; 2017.502 с.

10. Neitemeier S, Jelinek A, Laino V, Hoffmann L, Eisenbach I, Eying R, et al. BID links ferroptosis to mitochondrial cell death pathways. Redox Biol. 2017 Aug; 12: 558-79. DOI: 10.1016/j.redox.2017.03.007

Стаття надійшла 15.07.2021 p. Контакти: katerina142@ukr.net and medical-hygienic consequences of the Chornobyl catastrophe: ways of cognition and overcoming: Practical manual for a family doctor. Uzhhorod: Patent; 2017. 502 p.

10. Neitemeier S, Jelinek A, Laino V, Hoffmann L, Eisenbach I, Eying R, et al. BID links ferroptosis to mitochondrial cell death pathways. Redox Biol. 2017 Aug; 12: 558-79. DOI: 10.1016/j.redox.2017.03.007 